\title{
Young and old forest in the boreal: critical stages of ecosystem dynamics and management under global change
}

\author{
Timo Kuuluvainen ${ }^{1 *}$ (I) and Sylvie Gauthier ${ }^{2}$
}

\begin{abstract}
The circumboreal forest encompasses diverse landscape structures, dynamics and forest age distributions determined by their physical setting, and historical and current disturbance regimes. However, due to intensifying forest utilisation, and in certain areas due to increasing natural disturbances, boreal forest age-class structures have changed rapidly, so that the proportion of old forest has substantially declined, while that of young post-harvest and post-natural-disturbance forest proportions have increased. In the future, with a warming climate in certain boreal regions, this trend may further be enhanced due to an increase in natural disturbances and large-scale use of forest biomass to replace fossil-based fuels and products.

The major drivers of change of forest age class distributions and structures include the use of clearcut shortrotation harvesting, more frequent and severe natural disturbances due to climate warming in certain regions. The decline in old forest area, and increase in managed young forest lacking natural post-disturbance structural legacies, represent a major transformation in the ecological conditions of the boreal forest beyond historical limits of variability. This may introduce a threat to biodiversity, ecosystem resilience and long-term adaptive capacity of the forest ecosystem.

To safeguard boreal forest biodiversity and ecosystem functioning, and to maintain the multiple services provided to societies by this forest biome, it is pivotal to maintain an adequate share and the ecological qualities of young postdisturbance stages, along with mature forest stages with old-growth characteristics. This requires management for natural post-disturbance legacy structures, and innovative use of diverse uneven-aged and continuous cover management approaches to maintain critical late-successional forest structures in landscapes.
\end{abstract}

Keywords: Adaptive capacity, Biodiversity, Boreal forest, Climate change, Forestry, Ecosystem services, Forest dynamics, Forest management, Resilience

\section{Background}

The boreal forest provides humankind with essential ecological goods and services, and resources for economies at local, regional and international levels (Burton et al. 2010). Approximately two-thirds of the boreal forest is currently under some kind of utilisation (Gauthier et al. 2015a). The circumboreal forest contains more than one third of all terrestrial carbon, which is comparable to or more than that of tropical forests (Pan et al. 2011; Bradshaw and Warkentin 2015). At the same

\footnotetext{
* Correspondence: Timo.Kuuluvainen@helsinki.fi

'Department of Forest Sciences, University of Helsinki, Latokartanonkaari 7, FIN-00014 Helsinki, Finland

Full list of author information is available at the end of the article
}

time, this biome comprises a large share of the world's remaining forest ecosystems with negligible human impact (Bradshaw et al. 2009).

Even if the number of tree species is generally low, a single boreal forest stand can contain some 2500-5000 species (Kuuluvainen and Siitonen 2013), suggesting highly complex interaction webs (Burton 2013). A large share of the boreal species can be considered generalists. However, certain species are strictly confined to specific habitats, especially those found predominantly in natural forests (Nordén et al. 2013) and in specific conditions such as post-fire (Nappi et al. 2010) or old forest (Bergeron and Fenton 2012). These species are known to be most vulnerable to changes in climatic and forest 
structural conditions (Fenton and Bergeron 2008; Nordén et al. 2013).

In pristine conditions, boreal vegetation dynamics are driven by various types of natural disturbances acting over a range of spatial and temporal scales. These include large intense fires (Boulanger et al. 2014), low-intensity ground fires (Shorohova et al. 2011) and insect outbreaks (Régnière et al. 2012), which shape forest stand age structure at the landscape level, to finer scales but more continuous perturbations such as the deaths of individual trees or small tree groups (McCarthy 2001; Kneeshaw et al. 2011; Kuuluvainen and Aakala 2011). Disturbances of varying severity and operating at different and nested spatio-temporal scales result in heterogeneous stand age distributions and landscape mosaics, to which native biodiversity has adapted during their evolution. From the standpoint of biodiversity and ecosystem functioning, especially young post-disturbance forest (Swanson et al. 2011) and old late-successional forest (Shorohova et al. 2011) are particularly critical developmental stages in this forest mosaic.

When striving for ecosystem management, it is important to understand not only natural forest dynamics, but also how humans have impacted forest structures through times. Throughout the Holocene, ever since people inhabited the different boreal regions, they have affected forests in one way or another (Josefsson et al. 2009). For early forest dwellers, the forest was a source of raw materials, food, energy and various other services. Since medieval times in Europe, the rapidly increasing human population led to strong modification and agricultural use of the southern boreal forest. From late 19th century the circumboreal forest has been impacted more and more by industrial-scale forestry. Currently the boreal forest, especially in its southern regions, is managed primarily for timber production and to a small but increasing extent, for bioenergy (Brandt et al. 2013; Helmisaari et al. 2014).

Changes in mean annual temperature and precipitation regimes have already been reported in the boreal biome (McKenney et al. 2006; Groisman et al. 2017), and future projections suggest rapid temperature increases of $3.3-5.4{ }^{\circ} \mathrm{C}$ by $2071-2100$ compared with levels meassured 1961-1990 (Lindner et al. 2010; Price et al. 2013). These changes will notably impact boreal forest ecosystems through the change in disturbance regimes. Both abiotic disturbances (fire, extreme events such as droughts and windstorms) or biotic disturbances (outbreaks of native or invasive insects, fungi and other pathogens) are predicted to increase in frequency, intensity or severity under future climatic conditions (Flannigan et al. 2005, 2009; Lindner et al. 2010; Allen et al. 2010; Aakala et al. 2011; Régnière et al. 2012; Langor et al. 2014). The likely impact of this is an increased proportion of early successional forest and a decrease in the proportion of older forest.

The combined and cumulative effects of accelerating natural resource utilisation and warming climate are predicted to strongly alter boreal forest ecosystem dynamics, structures and composition and, hence, the age class mosaic of boreal forest landscapes. Climate is changing most rapidly at high latitudes affecting the forests directly by causing environmental stresses such as drought (Aakala et al. 2011; Price et al. 2013; Groisman et al. 2017), and indirectly through changes in disturbance regimes (Gauthier et al. 2015a). Other global change impacts, such as multiple and cumulative impacts of resources management and land use, from forestry, oil and gas exploration and invasive species, are also occurring with potential adverse effects on the health of the boreal forest (Gauthier et al. 2015a). The impacts of these drivers are most clearly visible in the change in the properties and structure of the successional stage mosaics of forest landscapes (Fig. 1a).

What is taking place all across the boreal forest is that the area of old late-successional forest is rapidly decreasing and is being replaced by young post-harvest or post-disturbance forest (Cyr et al. 2009; Kuuluvainen 2009). This change in the forest's coarse-scale structure is likely to have fundamental impacts on the ecological properties of the forest, including its biodiversity, ecosystem resilience and ability to store carbon (Bradshaw et al. 2009).

In this paper, we review and discuss the ecology of and prospects for ecosystem management of the boreal forest under global change risks. We define forest ecosystem management as a system aiming at maintaining key ecosystem properties, such as biodiversity, functioning and resilience, by minimising the differences between managed and natural ecosystems in terms of forest structure and composition at various scales (Gauthier et al. 2009c, 2009a, 2009b). Using north-eastern Canada and Fennoscandia as examples, we 1) discuss the key ecosystem management challenges in the boreal forest; 2) review disturbance regimes, and the resulting forest successional stage distributions, as an ecological basis of ecosystem management; 3 ) describe how forest management and global change have affected, and will likely affect, the distribution of forest successional stages, in particular the amount and quality of young post-disturbance and old forests; and 4) discuss how forest ecosystem management principles can be used to mitigate the adverse impacts and risks brought about by changing forest age distributions.

\section{Human impact and ecosystem management challenges}

Throughout the boreal zone, forests, forestry and forest industry play a key role in the economy and livelihoods 

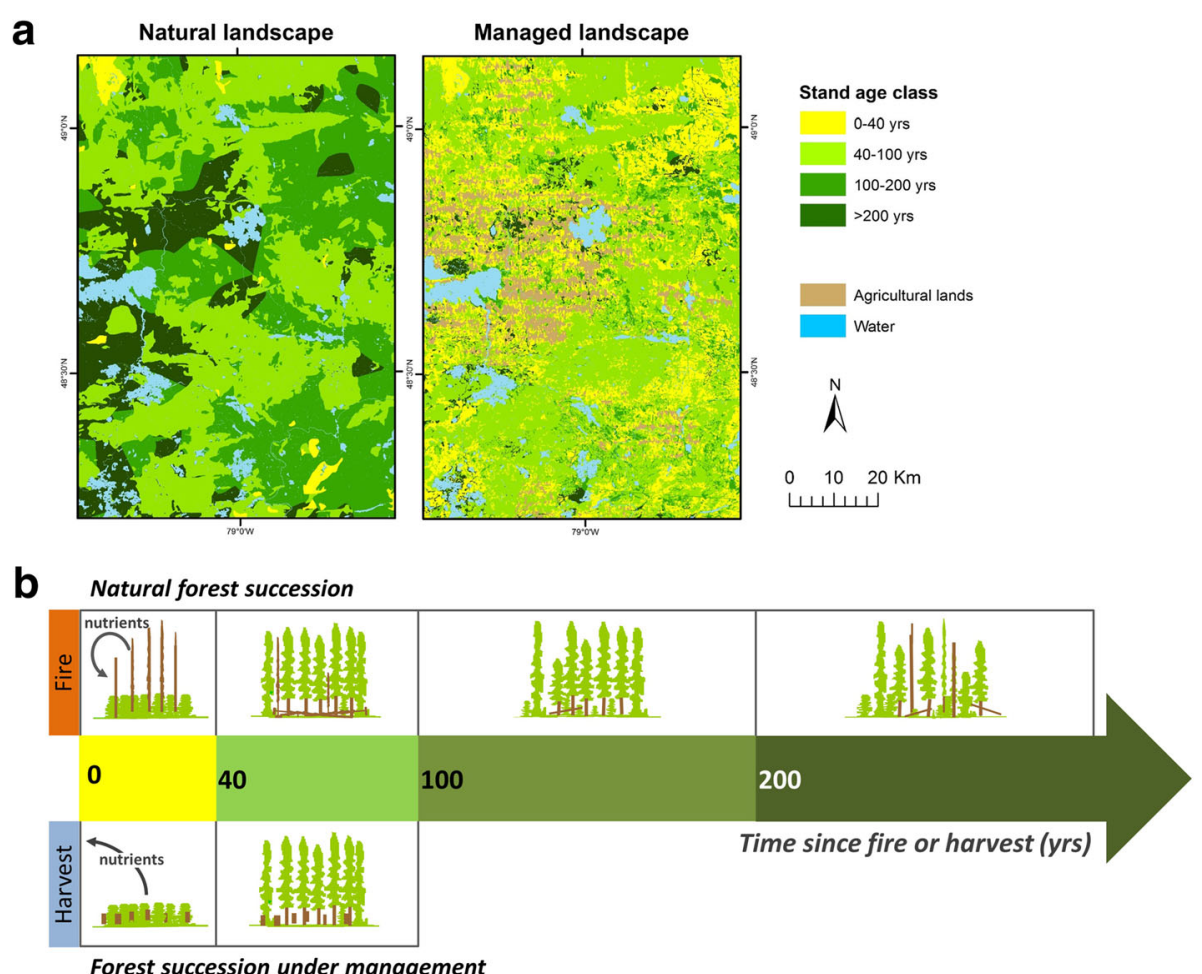

Fig. 1 An illustration of typical differences in forest landscape age class mosaic and forest stand structure and development in natural versus managed forest. a A natural landscape that was originally mostly composed of large patches of mature or old forest is fragmented into a finer scale patchwork of young forest. The landscape example comes from north eastern Canada, from the Lake Abitibi region at the border between Ontario and Québec. $\mathbf{b}$ Illustration of the difference in the length of time since disturbance and stand development between natural and managed forests. For Fig. 1a the natural landscape age classes are derived from Bergeron et al. (2004), while those of the managed landscape are derived from the Québec forest inventory map of the 3rd decadal program (1990)

of people and societies. Traditionally, boreal forest management has focussed on provisioning of continuous and preferably increasing availability of woody raw material and protection from natural disturbances. This approach is called sustained yield management (Puettmann et al. 2009). Since the 1990s, sustainable forest management principles have been diversified and redefined to encompass a wider array of environmental, economic and societal values and goals, such as biodiversity conservation, productivity maintenance, global biogeochemical cycles and socio-economic benefits.

Currently the grand challenges of forest ecosystem management are to maintain economic and social sustainability and at the same time mitigate and adapt to climate change, and safeguard biodiversity and related ecosystem services (Bradshaw et al. 2009; Gauthier et al. 2015a). These challenges in different combinations are omnipresent across the circumboreal regions with different histories, and natural and social settings (Angelstam et al. 2011). These differences can be exemplified by comparing the situation in two boreal regions, north-eastern Canada and Fennoscandia (Table 1).
In both regions forestry and forest industry form an important part of the economy, forest resources are used efficiently and the dominating management practise is even-aged management, where final harvesting is done by clearcutting. However, there are important differences between the two regions. In eastern Canada, industrial-scale forest management has been mostly extensive, while in Fennoscandia most of the forest is under intensive management (Table 1). In north-eastern Canada Industrial-scale management is also more recent and at the beginning of this century, less area than the area of productive forest had been harvested once (Burton et al. 2003; Venier et al. 2014). In most parts of Fennoscandia efficient forest utilisation has lasted longer, has been more diverse and intensive, and is currently increasingly based on cutting second growth forests (Esseen 1997; Keto-Tokoi and Kuuluvainen 2014).

Both in north-eastern Canada and Fennoscandia, the dominating even-aged management practice has had, and continues to have, a major impact on forest landscape characteristics, such as patch size distributions and proportions of early- versus late-successional forest stages (Table 1; Fig. 1). These changes are illustrated in 
Table 1 Comparison of the main features of forests and forestry, and the condition of young and old forest successional stages, in north-eastern Canada and Fennoscandia

\begin{tabular}{lll}
\hline & North-eastern Canada & Fennoscandia \\
\hline $\begin{array}{l}\text { Type of management } \\
\text { Type of forest harvested }\end{array}$ & Extensive & Intensive \\
& $\begin{array}{l}\text { Cutting natural forest and moving towards north. } \\
\text { In certain regions starting to harvest second } \\
\text { growth forests }\end{array}$ & $\begin{array}{l}\text { Cutting mostly second growth as forest mostly } \\
\text { managed. Some natural forest still harvested }\end{array}$ \\
Dominant management type & $\begin{array}{l}\text { Even-aged management with clearcutting } \\
\text { and advance regeneration protection }\end{array}$ & $\begin{array}{l}\text { Even-aged management with clearcutting } \\
\text { followed by planting with native species }\end{array}$ \\
$\begin{array}{l}\text { Protected productive forest } \\
\begin{array}{l}\text { Cutting rotation vs natural } \\
\text { disturbance (fire) cycle }\end{array}\end{array}$ & $\begin{array}{l}\text { Rotation 60-90 years for Black spruce forests; } \\
\text { fire cycle 90-300 years }\end{array}$ & R 6\% (regionally highly variable) \\
& & Rotation 60-120 depending on site type and \\
& & geographic location; fire cycle 60-300+ years \\
& &
\end{tabular}

\section{Old forest}

Quantity

Quality

Dead wood amounts

Threats

Young forest

Quantity

Quality

Management practises

Threats

\author{
Decreased but still remain in large patches \\ in certain regions \\ Partly natural, in northern less productive areas \\ $17-160 \mathrm{~m}^{3} \cdot \mathrm{ha}^{-1}$ in natural vs. $10-153 \mathrm{~m}^{3} \cdot \mathrm{ha}^{-1}$ \\ in managed forests \\ Cuttings, climate change, increasing disturbances
}

Increased

Natural regeneration after clearcut harvesting in parts
Natural regeneration after natural disturbances in parts
Increasing amount of salvage logging after natural disturbance, regeneration failure

\begin{abstract}
Amount collapsed but some larger patches remain in northern protected less productive areas

Partly natural, in northern protected less productive areas

60-120 $\mathrm{m}^{3} \cdot \mathrm{ha}^{-1}$ in natural vs. 4-10 $\mathrm{m}^{3} \cdot \mathrm{ha}^{-1}$ in managed forests

Cuttings, climate change, increasing disturbances
\end{abstract}

Fig. 1a, depicting a real landscape in western Québec and showing how management has resulted in the decline in patch sizes and old forests. In fact, the natural landscape was characterised by large tracks of forests older than 200 years, whereas in the managed landscape the remaining old forests are now scattered among younger forest, which has increased considerably (Fig. 1). The decrease in the amount of old forest is in part due to harvesting cycles, which are much shorter than natural disturbance cycles (Fig. 1a and b; Table 1). The situation is similar in Fennoscandian landscapes, where old forest is equally scarce and the managed forest landscape is even more regulated compared with north-eastern Canada (Kuuluvainen 2009; Angelstam et al. 2011).

Such major changes in forest landscape 'architecture' have obvious consequences on tree species composition and structural biodiversity attributes of forests. In particular, the proportion of young stands with early successional tree species has increased at the expense of older stands and late successional tree species (Table 1; Cyr et al. 2009; Kuuluvainen 2009). This means decline in big trees with cavities, large snags and large standing and downed dead wood, which detrimentally affects ecological processes and increase pressure to organisms dependent on such habitat features (Hanski 2000; Nordén et al. 2013).

In Fennoscandia, it has been shown how the loss of natural structural elements in managed forests has led to the decline of biodiversity (Auvinen et al. 2007; Kuuluvainen and Siitonen 2013). For example, in Finnish managed forests the decline of dead wood amounts is estimated to be the main cause of species becoming threatened for one-third of the threatened forest species (over 500 species) (Rassi et al. 2010). In Finnish managed forests there are on average $4-6 \mathrm{~m}^{3} \cdot \mathrm{ha}^{-1}$ of dead wood, which is less than $10 \%$ of natural levels (Siitonen 2001). Obviously such low levels of dead wood are below the threshold of species that demand more natural deadwood habitat conditions (Nordén et al. 2013). The national and European Union -level ambitions to increase forest biomass harvesting to replace fossil fuels would likely lead to further decline in dead wood and related diversity in forests, as well as the forest carbon store and sink in short term at least (Helmisaari et al. 2014; EASAC 2017). Notably the dead wood levels in the managed boreal forests of eastern Canada are much higher 
compared with Fennoscandia, apparently due to differences in management and natural legacies (Table 1). However, these natural legacies of dead wood will probably decay and diminish with time and intensifying management, as has happened in Fennoscandian managed forests.

Disappearance of natural features (quality) in managed forests is usually accompanied by decline in the area of natural forests (quantity) (Fig. 1). In Fennoscandia, the decline of natural forests has been a long process, including various historical uses of forests. However, the decline and the fragmentation of the remaining natural forest profoundly accelerated with the rise of forest industry and intensification of forest management after World War II (Esseen et al. 1997; Keto-Tokoi and Kuuluvainen 2014). The result of this historical processs is that most of the remaining natural protected forest is situated in the northern low-productivity areas (Angelstam and Andersson 2001), whereas only small fragments of isolated natural forest remain protected in southern areas. This makes rehabilitation of natural forest habitats and establishment of functional protection area networks in southern high biodiversity forests difficult and expensive, notably as it would probably require patient large-scale restoration of managed forest designated as new protected areas (Angelstam and Andersson 2001; Halme et al. 2013). Such a situation highlights the importance of the quality of the managed forest matrix in attaining ecosystem management goals (Lindenmayer and Franklin 2002).

Compared with Fennoscandia, where forests have been in one way or other utilised for centuries and a large share of forests are under their second intensive rotation, in north-eastern Canada harvesting is still mostly taking place in natural forest in the north. In these forests, when possible, regeneration is provided by harvesting with protection of advance regeneration and soil, while plantation (mostly with native species) is also used to insure the maintenance of forest productivity. The harvested natural forest also has structural legacies such as dead wood pools which only slowly start decaying away after first cutting. Overall, this means that the forests under management in north-eastern Canada currently have more natural legacies left in the forest as compared to Fennoscandia (e.g. dead wood) and that there is still a potential for proactive design of forest landscapes and protection area networks based on current scientific knowledge and considering anticipated climate change effects on species range shifts.

The comparison of north-eastern Canada and Fennoscandia shows that the history of forest management strongly affects the means, approaches and possibilities for practising ecosystem management by focusing on key ecosystem characteristics such as quantity and quality of young and old forest developmental stages. In Fennoscandia, attaining more sustainable levels of natural forest habitat (e.g. 10\% or natural levels) requires large-scale restoration of managed forest, whereas in Canada the question is more on how to harvest to maintain existing key ecosystem qualities and quantities (Gauthier et al. 2009a; Kuuluvainen 2009; Angelstam and Anderson 2001). In both cases it is important to understand the ecology of the structure and dynamics of the forest ecosystem, where natural disturbance regime plays a key role. Based on this notion, region-specific emulation of natural disturbances (END) has been proposed as a relevant approach in forest ecosystem management (Bergeron et al. 2002; Gauthier et al. 2009b; Kuuluvainen and Grenfell 2012).

\section{Historical disturbance regimes and successional stage distributions in the North Atlantic boreal forest}

Understanding natural disturbances and their impact on forest structure is important, because they largely determine the spatio-temporal dynamics of forest successional stages and the habitat mosaic structures available for forest-dwelling species (Pickett and White 1985). Past forest structural conditions represent an ecological and evolutionary template, in which the ecosystem and its species have developed. To evaluate the current ecological condition of forests, and how it has developed and may develop in the future, it is imperative to understand both past and present forest disturbance regimes, and their impacts on forest ecosystems from local stand to regional scales (Bartemucci et al. 2002; Shorohova et al. 2009; Kneeshaw et al. 2011; Kuuluvainen and Aakala 2011; Bergeron and Fenton 2012).

Certain older descriptions characterise the boreal forest as composed of monospecific post-fire stands, where fires are frequent enough to prevent old forest characteristics from developing (Fig. 2a; Johnson 1992; Payette 1992). Although such situations and forests exist, research carried out during the past decades, notably in North Atlantic boreal forests, has revealed a very different overall picture of intrinsic boreal forest structure and dynamics. In north-eastern Canada, for example, stand replacing fires are less frequent than in central Canada, resulting at a higher natural representation of stands of old age (Bergeron et al. 2001; Bélisle et al. 2011). In the Fennoscandian situation, non-stand replacing disturbances such as low to medium-severity fires, windstorms and insect outbreaks, have historically been common (Fig. 2c and d; Kuuluvainen 2009; Shorohova et al. 2009), resulting in stand structures with multiple tree age cohorts and small-scale gap/patch dynamics in late-successional forests (Gromtsev 2002; Kuuluvainen 2009; Kuuluvainen and Aakala 2011). However, due to intensive forest management, natural disturbances are rare and forest structure and dynamics are 

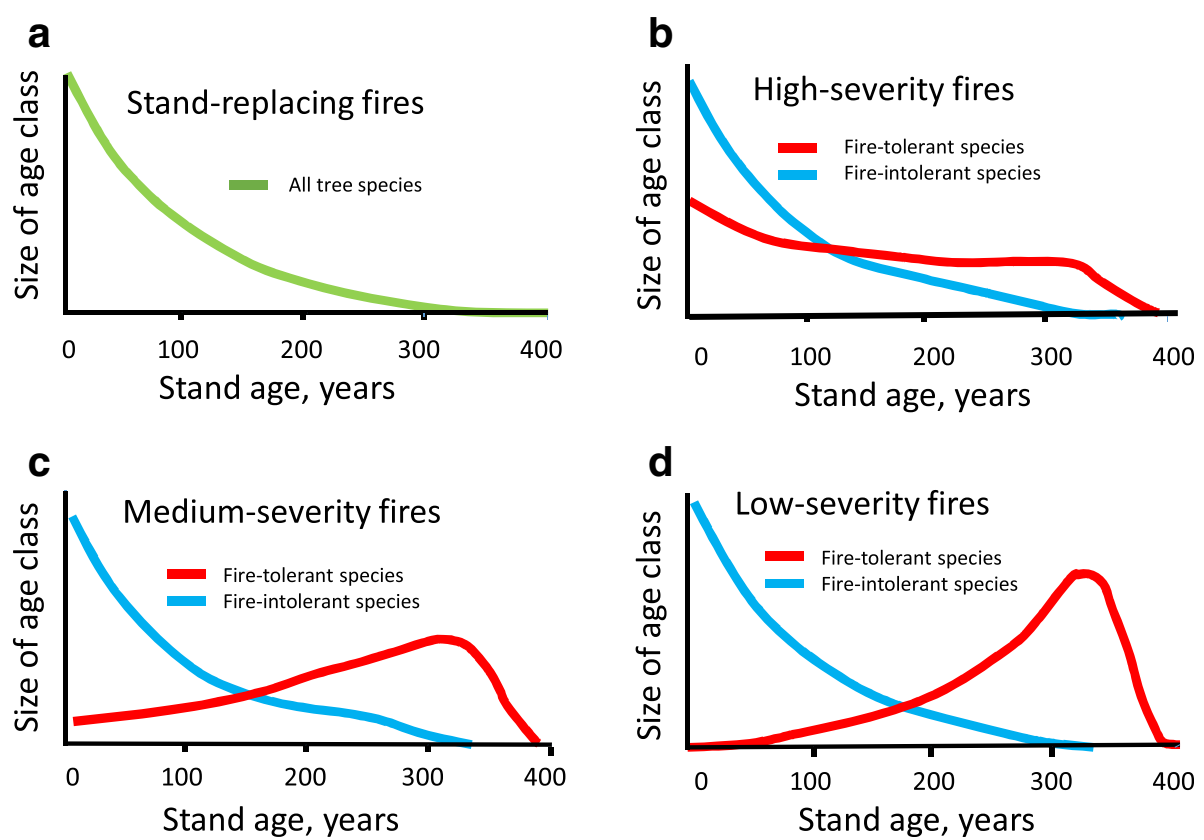

Fig. 2 A model based illustration of how forest stand age distribution and species composition at the landscape level depends on the interaction between fire regime and tree species traits. Young forest cover a major part of the landscape when disturbances are stand-replacing or severe. The share of old forest is emphasized when disturbances are of medium to low severity. a All fires are stand-replacing. b High-severity fires prevail, but some fire-tolerant species survive fires. c Fires are of moderate severity. $\mathbf{d}$ Low-severity fires dominate and large fire-tolerant species survive. The figure is redrawn from Pennanen's (2002) Fig. 2; the results are based on model simulations and represent steady-state distributions, where the fire rotation was 95 years. Stand age is classified based on the oldest tree cohort (for details see Pennanen 2002)

controlled by management disturbances. Forest fires, in particular, are efficiently extinguished due to the dense forest road network.

In contrast to the earlier views, structurally diverse late-successional forests appear to be common in boreal forest landscapes, either because disturbance return times are long as in north eastern Canada (Shorohova et al. 2009), or because forest dynamics are driven by a diverse set of partial or non-stand-replacing disturbances (Kuuluvainen and Aakala 2011, Fig. 2b, c, d). Importantly, the characteristics and definition of old-growth forest vary according to dominance of disturbance types and severities, and tree species resistance and response traits to these disturbances (Fig. 2). For example, the ecological impact of fire on forest structure and successional stage distributions finally depends on tree species resistance to disturbance and tree species traits, such as regeneration strategy (Fig. 2; Rogers et al. 2015; Sánchez-Pinillos et al. 2016).

In areas where fire return intervals are long (longer than median natural longevity of the main tree species) or low-intensity surface fires dominate, old forest dominate and autogenic disturbances such as tree senescence-related insect outbreaks, fungi and windthrow become important small-scale drivers of forest structure and dynamics (Fig. 1; McCarthy 2001). Such dynamics is naturally common in much of the North Atlantic forest under maritime or semi-maritime climate (Kneeshaw et al. 2011; Kuuluvainen and Aakala 2011). It is most commonly the case, however, that a variable set of different allogenic and autogenic disturbances are jointly driving the dynamics of boreal forest landscapes.

It becomes clear from this short summary that the intrinsic structures and dynamics of forests vary at multiple scales, from local stand to regional, and up to continental scales. This emphasises the importance of local knowledge of forest ecology when setting goals for ecosystem management. However, in addition to intrinsic dynamics, anthropogenic drivers also need to be considered.

\section{Lessons from North Atlantic forest management}

Global change drivers, including direct human impacts and climate change effects, are strongly affecting the circumboreal forest, changing forest structure and dynamics, and the distribution of young versus old forest compared with historical conditions (Table 1; Cyr et al. 2009; Kuuluvainen 2009). Not only does the area of post-disturbance forest increase substantially, but also the ecological quality of forest change compared to natural young forest. At the same time, a concomitant decrease in the share of old forests, and their ecological 
quality, is concurrently taking place, and is predicted to continue in the future (Fig. 3; Kuuluvainen 2009). The question then is, what are the ecological consequences of this vast shift in boreal forest ecosystem structure and what could be done to mitigate the concomitant adverse impacts? We discuss this by reviewing the lessons learned from two contrasting regions with intensive versus extensive forest management regimes.

\section{Fennoscandia: increasing timber yield but declining biodiversity}

Within the boreal zone, the forests in Fennoscandian countries (Finland, Sweden and Norway) have been under the most intensive and long-lasting utilization (Table 1). These forests have been shaped by a historical sequence of various and regionally variable human uses, from primitive hunter-gatherers to slash-and-burn agriculture and selective logging of best sawn timber, to modern plantation-type intensive forestry (Josefsson et al. 2009). Old natural forest on the whole disappeared as early as some hundreds of years ago in the southern Fennoscandia, but this decline has taken place more recently in the northern parts (Keto-Tokoi and Kuuluvainen 2014, page 219). Because of long traditions in taxonomic studies, the characteristics and changes of forest biota in response to human actions are perhaps better known than anywhere else. This has also facilitated the evaluation of the long-term impact of intensive forestry on forests and their biota (Kuuluvainen and Siitonen 2013).

The intensive Scandinavian model of forest management, based on growing fully stocked even-aged stands

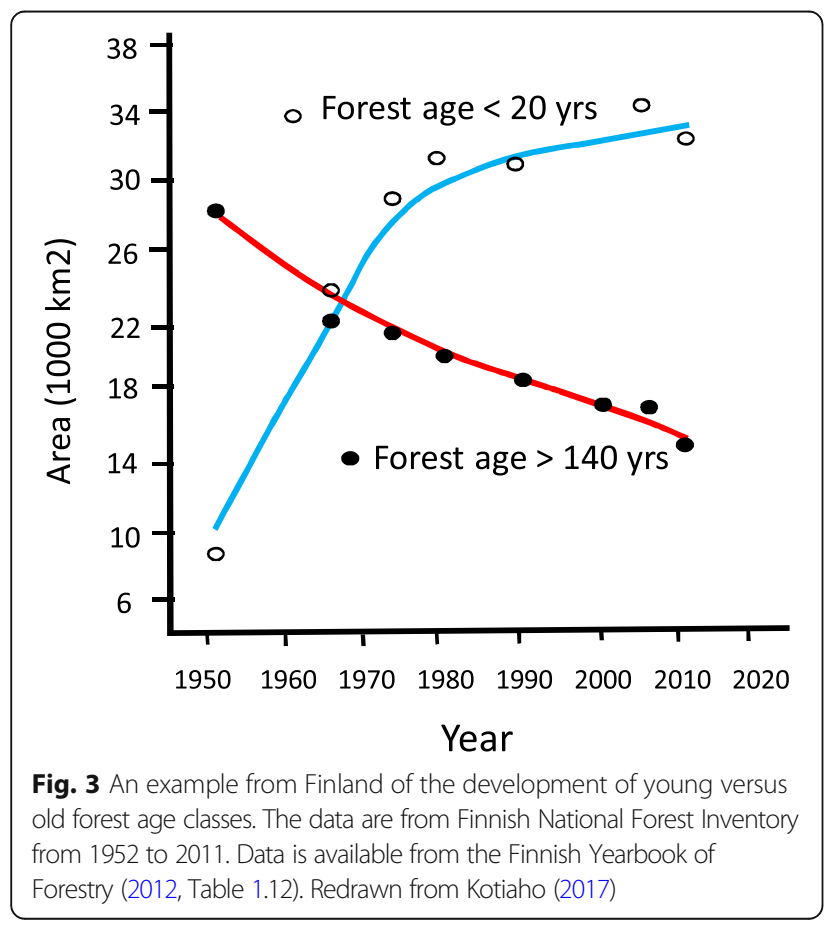

with short rotation cycles (compared with natural stand dynamics; Fig. 1b), has been successful in increasing timber volume and growth (which are continuously increasing). However, this management approach has caused profound ecological changes in forest ecosystem structure and functioning, the most significant ones being the suppression of natural disturbances (especially low and medium intensity fires), the decline and fragmentation of old forest with natural legacies, an increase in homogeneous young forest following clearcutting, and an decline in quantity and diversity of dead wood (Fig. 1; Kouki et al. 2001; Siitonen 2001; Kuuluvainen 2009). The overall result has been a decline in the diversity and ecological variability of forest habitats, and their associated species (Berg et al. 1994; Rassi et al. 2010; Nordén et al. 2013). For example in Finland 35\% of threatened forest species use old forest as their main habitat (Rassi et al. 2010), and 70\% of forest habitats was classified as threatened, often due to qualitative deterioration such as reduced amounts of dead wood and simplified stand structure (Raunio et al. 2008).

The Scandinavian experience shows that focusing on sustainable timber yield management and increasing timber production are not necessarily compatible with broader sustainability goals, including biodiversity conservation and maintenance of multiple ecosystem services (Kuuluvainen 2009; Peura et al. 2018). In particular, anthropogenic disturbances from even-aged forests management lead to a decline in late-successional forest structures and an increase in structurally monotonous young forest, mostly originating from plantings. This can in the long run cause local extinctions of species, which depend on natural forests and their specific properties, such as diverse dead wood (Hanski 2000; Rassi et al. 2010). In Fennoscandia, the grand challenges of ecosystem management are to reverse the trend in declining biodiversity and patiently strive for a more balanced state between different dimensions of sustainability.

\section{North-Eastern Canada: changes in the quantity and quality of young forest}

The ecological value of old forest has been emphasized for a long time, but recently the importance of young forest with natural post-disturbance characteristics has also been highlighted (Swanson et al. 2011). The areas of young and old forests have been increasing and decreasing, respectively, in eastern Canadian forests under extensive management, as compared to the natural variability observed during the Holocene (Table 1; Cyr et al. 2009). The proportion of post-disturbance developmental stages of forest are predicted to increase (Table 2) with the projected warming climate and in certain regions of eastern Canada the amount of young forest may 


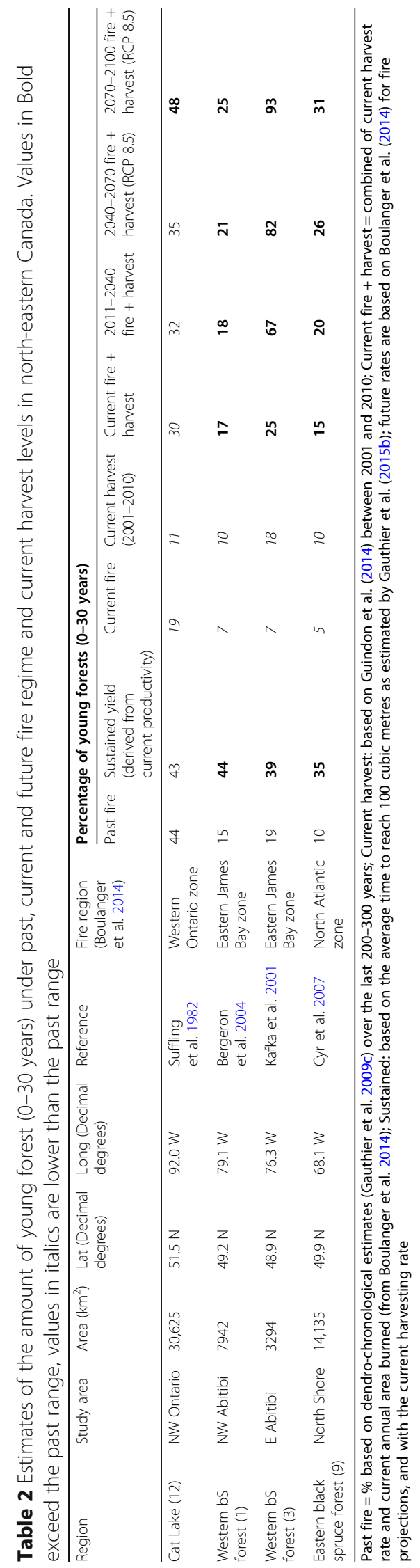


reach levels that are outside the natural range of variability observed in the past 200-300 years.

Table 2 provides an example of four regions of northeastern Canada in terms of potential change in the importance of young forests (0-30 years) in landscapes as compared to past historical distribution. When future fire projection is compiled and added to the current harvesting levels, a higher proportion of young forest as compared to the past is predicted (Table 2).

With current and future drivers of change, the share of young forests would not only be increasing, but their quality could also be declining both because of both post-harvesting management practices and increased salvage logging (Venier et al. 2014). In terms of habitat quality, natural disturbance sites have important structural legacies, such as dead burned trees, dead wood, regenerating shrubs and herbaceous plants, which make this forest stage an important habitat for a large number of organisms.

Moreover, recently disturbed ecosystems are changing and developing rapidly on a year to year basis. They are thus characterised by both high biodiversity and high species and habitat type turnover (Boulanger and Sirois 2007; Angers et al. 2011). These diversity of species and dynamics also depends on the type, intensity and severity of disturbances (Nappi et al. 2010). In natural conditions, the post-disturbance stage with specific legacies is crucial for ecosystem adaptation, because then the system can reorganise with the emergence of new combinations of species and genetic materials facilitating adaptation to new conditions (Lindenmayer et al. 2013; Gauthier et al. 2014; Swanson et al. 2011).

In contrast to natural forest, in managed forest this post-disturbance (post-harvest) stage has low diversity of structural legacies and forest regeneration is often controlled through tree planting and vegetation control, and/or pre-commercial thinning. This situation tends to create more homogeneous and less diverse stands, which may impair the adaptive capacity of the forest ecosystem to novel conditions. In eastern Canada, however, large portions of harvested areas are naturally regenerated, thereby creating heterogeneity in the young forest stages as compared to Fennoscandia where this phase is generally more strictly controlled (Kuuluvainen and Siitonen 2013; Venier et al. 2014). However, certain differences between fire and harvesting with soil protection and advanced regeneration are recognised in the legacies of forest composition or soil fertility (Carleton and Maclellan 1994; Nguyen-Xuan et al. 2000; Venier et al. 2014; Maynard et al. 2014), with potential impacts on biodiversity.

To compensate for the economic losses due to fire, insect outbreaks or windstorm damages in timber production forest, the practice of salvage logging has increased, notably in eastern North American boreal forest (Nappi et al. 2004; Schmiegelow et al., 2006; Saint-Germain and Greene 2009; Venier et al. 2014). Although post fire salvage logging is currently less important in Fennoscandia, the large Westmanland fire in 2014 in Sweden lifted this issue onto the table also in northern Europe. Moreover, future disturbance rate may increase the use of this practice throughout the boreal forest.

Salvage logging has been shown to impact several ecosystem functions: after such double disturbances (natural and human-caused) the short-term recovery of a forest can be slowed for coniferous trees (Greene et al. 2006), and for numerous species that are associated with deadwood (Thorn et al. 2017) or that require special disturbance features such as uprooting pits and mounds (Waldron et al. 2013) for their development. Salvage logging can also change the landscape share of different stand composition types by favoring deciduous trees over coniferous ones (Lindenmayer et al. 2013; Boucher et al. 2014).

\section{Why and how to restore and manage for young and old forests proportions in landscapes?}

In the preceding sections we have shown that both in north-eastern Canada and Fennoscandia, major changes in quantity and quality of young and old forest stages have taken place during the recent past, with potential adverse and cumulative impacts on ecosystem functioning, biodiversity and resilience. Furthermore, the climate, which is projected to become dryer in certain regions (notably in the eastern parts of Fennoscandia), can also influence the resilience of the closed forest, possibly favoring development toward more opened forests (Scheffer et al. 2012; Fig. 4). To mitigate such risks several approaches based on ecosystem management principles have been suggested (Gauthier et al. 2009b; Kuuluvainen 2016), although their wide application has not occurred yet.

The increased share of young forests in landscapes can create forest mosaics which are more vulnerable to a regeneration failure (Jasinski and Payette 2005; Girard et al. 2008; Splawinski et al. 2018), have greater sensitivity to climatic anomalies, such as drought or early/late frost (which might be expected to increase under climate change, Stevens-Rumann et al. 2017), and which have higher risk for opportunistic species invasions as climate becomes more benign for them (Dukes et al. 2009). In an increasingly fragmented landscape, species requiring natural forest habitat may face high risk of population decline and local extinctions (Hanski 2000). These vulnerabilities can be further amplified by the general simplification of ecosystem structure due to the general use of clearcut harvesting and even-aged forest management (Fig. 1).

The extent of even-aged management needs to be reduced to maintain desired proportions of young and old forest age classes in landscapes, and hence to maintain 


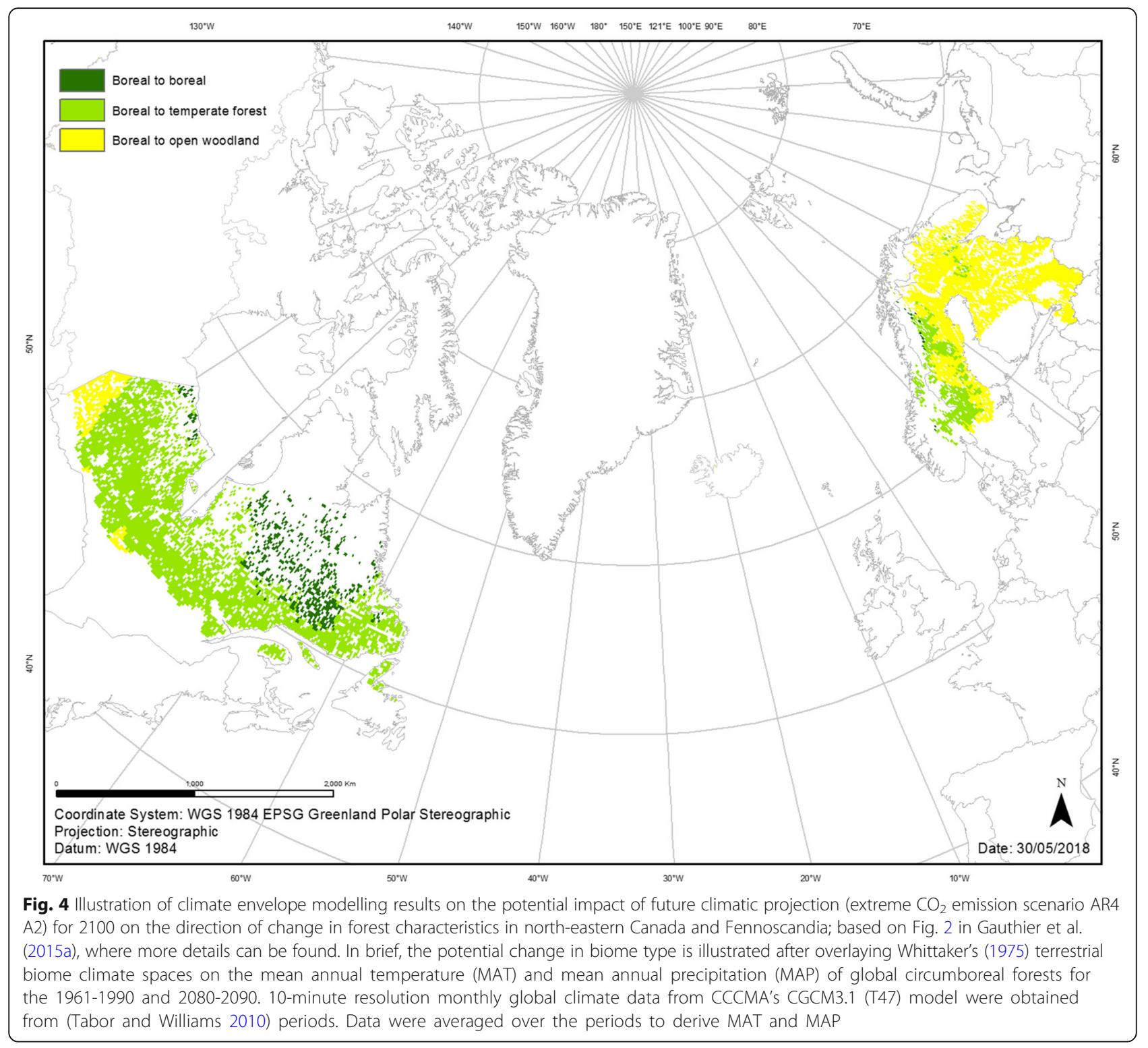

biodiversity and mitigate the risks of future disturbances. Limiting the amount of young forests and increasing the share of stands with old forest characteristics is important. This points toward the need to increase uneven-aged and/or continuous cover forest management approaches to maintain desired levels of late-successional trees and forests in landscapes (Bauhus et al. 2009; Kuuluvainen 2009; Peura et al. 2018). Depending on conditions, these management approaches may alleviate certain ecological problems associated with current management approaches (e.g. Kuuluvainen et al. 2012; Peura et al. 2018), along with providing an economically attractive alternative (Pukkala et al. 2011; Kuuluvainen et al. 2012; Rämö and Tahvonen 2014). For example, Pukkala et al. (2016) found that uneven-aged stands were less prone to windthrow compared with even-aged stands. Similarly, Leduc et al. (2015) observed that landscape with a high share of old forest were less vulnerable to increases in the annual area burned.

To maintain desired proportions of young and old forest age classes, managers should pay special attention to risks posed by an increase in natural disturbances (Savage et al. 2010; Raulier et al. 2013). This is important to avoid overharvesting and associated rapid changes in forest age class distribution. This also creates a need to forest policies find economic incentives for changing current practices (Moen et al. 2014). More studies looking at trade-offs and synergies between different management approaches could help find solutions that are ecologically and economically feasible. Managing to optimise value rather than volume, can also be a good practice for decreasing the level of harvesting (Rijal 2017). 
Designation of protected areas, where processes are left to occur without direct human intervention, is one way to maintain biodiversity and the adaptive capacity of the boreal forest (Andrew et al. 2014). Hannah et al. (2007) suggest that to allow for adaptation to take place in the context of global change, more protected area is required, emphasising the need to increase the conservation efforts in the managed portion of the boreal forest (Andrew et al. 2014).

The use of ecosystem management near and between protected areas can help the species to migrate and keep up with the change in climate (Pedlar et al. 2012). This argues in favor of the use of functional zoning approaches, such as the triad approach, in which the management unit is divided into three different zones where conservation, intensive timber production, and extensive management are applied (Seymour and Hunter 1992; McAfee et al. 2010). This can enable efficient planning for the various services from forests that are desired by society.

\section{How to restore natural characteristics of young and old forests?}

The maintenance of heterogeneity at the stand and landscape levels (i.e. habitat diversity) is pivotal for fostering forest resilience (Fig. 1; Campbell et al. 2009; Gauthier et al. 2009a). This is notably the case in terms of the qualities of both young and old forest stages. For example, conservation of at least one-third of the area of each fire could be necessary for maintaining the variety of forest composition/fire severity combinations needed to ensure the maintenance of biodiversity in recently burned areas (Nappi et al. 2011; Thorn et al. 2017). This would provide important post-disturbance habitat features, including pits and mounds, and burned and overall diversity of dead wood.

In areas with active fire dynamics, conservation of old forest can be achieved in areas large enough compared to the average size of fires, so that certain forest areas can escape fires. Forest can also be managed with longer rotation than those traditionally used (Burton et al. 1999). Adapted silviculture using the multi-cohort approach, where structural attributes are maintained or restored, is one approach (Bergeron et al. 1999). Attention could also be given to disturbing the soil to avoid phenomena such as the paludification, and that specific species are not overwhelmingly favoured or disfavorued, as has been the case in harvested sites in the north eastern boreal forest of Canada (Venier et al. 2014).

\section{Future prospects and vulnerabilities}

It has been suggested that the health of the boreal forest and its capacity to provide important goods and services to society (e.g. timber, biodiversity, clean water, regulation of global biochemical cycles, recreation) could be jeopardised because of the ongoing global changes (Gauthier et al. 2015a, 2015b). At the same time, it is evident that the inherent resilience of the boreal forest to environmental changes and stresses is in general relatively high. This is because, for example, most tree species have large environmental tolerance ranges, large population sizes, and high genetic variation within populations, as they are mostly wind pollinated (Aitken et al. 2008). Holocene studies also suggest that the tree species pool has regionally remained quite similar, despite drastic changes in climatic conditions and fire regimes (Carcaillet et al. 2010; Blarquez et al. 2014). This signals high inherent ecosystem resilience, which is promising considering the possibility of provisioning of ecosystem services in the future.

We must be emphasise, however, that the future capacity of the boreal forest to adapt is difficult to assess. This is because of the quality and speed of the forecasted changes, which are unparalleled and novel compared to past ecological history. Moreover, the cumulative effects of past and ongoing management practices are largely unknown and may already have reduced the biodiversity and adaptive capacity of the boreal forest to face the upcoming rapid changes in environmental conditions (Gauthier et al. 2015a).

Throughout the circumboreal zone, industrial scale forest management, together with other resource utilisation and natural disturbances, have drastically decreased the proportion of old forest and increased the share of young post-disturbance forest as compared to past historical conditions (Cyr et al. 2009; Kuuluvainen 2009). This development is likely to continue, and even accelerate, in the future, as the intensity of both forest utilisation and natural disturbances are expected to amplify in the future climatic conditions (Burton et al. 2010; Gauthier et al. 2015a, 2015b). Overall, these developments are excerting an unprecedentant structural transformations on the boreal forest ecosystem, with major repercussions and threads to key ecosystem properties and processes, such as biodiversity, carbon dynamics, ecosystem resilience and adaptive capacity.

\section{Conclusions and Recommendations}

Instead of optimising for a narrow range of commodity products, forest management should aim at maintaining a diversity of potential responses to face uncertain future conditions. Here, the ecological importance of young post-disturbance forests is perhaps overlooked the most. This ecosystem stage is pivotal for disturbance-associated ecosystem reorganisation, which provides an opportunity for ecosystem adaptation to changing environments through establisshment of new combinations of species and genotypes (Burton et al. 2013; Swanson et al. 2011). Under natural conditions, young 
post-disturbance forests are hosting a large number of organisms benefiting from open canopies, large amounts of woody debris, high structural diversity and above ground structure left by the disturbances (Siitonen 2001; Swanson et al. 2011). To safeguard the essential ecological functions of young forests, it is necessary to leave sufficient retention as critical post-disturbance habitat elements (Nappi et al. 2011; Lindenmayer et al. 2013).

In a warming climate, post-disturbance forest stages may also face increased risk of regeneration failure (Splawinski et al. 2018). This means that the post-disturbance stage may be crucial for maintaining ecosystem resilience (a situation which would warrant their monitoring) in the future. Management options aiming to avoid post-disturbance regeneration failures may include assisted species or provenance migrations, leaving natural disturbance legacies that enhance tree regeneration (Millar et al. 2007; O'Neill et al. 2008; Pedlar et al. 2012), and favouring of species or provenance mixtures that spread the risks and increase the probability of efficient utilisation of future growth conditions (Campbell et al. 2009).

Old forests are an essential, and often a dominant, component of unmanaged boreal forest landscapes (Kuuluvainen 2009; Bergeron and Fenton 2012). The ecological value and biodiversity of old forests has long been regoqnised (Kuuluvainen 2009; Bergeron and Fenton 2012). For example, they are known to harbour a number of specialised species, which are vulnerable to the decline in the quantity and quality of this habitat (e.g. Nordén et al. 2013). This indicates that old-growth forests are of high conservation priority (but see Fig. 3). In addition, silvicultural practices can be implemented to maintain or rehabilitate structural and compositional heterogeneity typical of late-successional forests. Such management can utilise approaches such as high-retention forestry, continuous-cover silviculture and management inspired by natural disturbances (Gustafsson et al. 2010; Burton and Macdonald 2011; Kuuluvainen and Grenfell 2012).

We call upon a holistic approach to landscape management, where specific attention is given to maintaining the proportion and ecological quality of young versus old forest characteristics, as inspired by naturally dynamic forest landscapes. We encourage further examination and innovative use of mixed management approaches, which strive to maximise positive synergies between key forest ecosystem services, such as carbon sequestration, economic profit and biodiversity maintenance (e.g. Pukkala 2016; Peura et al. 2018).

\section{Acknowledgements}

We thank Dominique Boucher and David Gervais for help in data collection and Stella Thompson for revision of the English language. This work was carried out in the framework of the EBOR-project funded by the 597 Academy of Finland (proj. no. 276255).

\section{Funding}

This work was carried out in the framework of the EBOR-project funded by the Academy of Finland (Proj. No. 276255).

\section{Authors' contributions}

Both authors equally participated in planning, data acquisition and writing of the study. Both authors have read and approved the final manuscript.

Ethics approval and consent to participate

Not applicable.

\section{Competing interests}

The authors declare that they have no competing interests.

\section{Author details}

'Department of Forest Sciences, University of Helsinki, Latokartanonkaari 7, FIN-00014 Helsinki, Finland. ${ }^{2}$ Natural Resources Canada, Canadian Forest Service, Laurentian Forestry Center, 1055 rue du P.E.P.S., C.P. 10380, succ. Sainte-Foy, Quebec, Québec G1V 4C7, Canada.

Received: 16 January 2018 Accepted: 24 May 2018

Published online: 13 June 2018

\section{References}

Aakala T, Kuuluvainen T, Wallenius T, Kauhanen H (2011) Tree mortality episodes in the intact Picea abies-dominated taiga in the Archaangelsk region of northern European Russia. J Veg Sci 22:322-333

Aitken SN, Yeaman S, Holliday JA, Wang T, Curtis-McLane S (2008). Adaptation, migration or extirpation: climate change outcomes for tree populations. Evol Appl 1(1):95-111

Allen CD, Maclady AK, Chenghouni H, Bachelet D, MacDovell N, Vennetier M, Kitzberger T, Rigling A, Breshears DD, Hogg EH, Gonzalez P, Fensham R, Zhang Z, Castro J, Demidova N, Lim J-H, Allard G, Running SW, Semerco A, Cobb N (2010) A global overview of drought and heat-induced tree mortality reveals emerging climate change risks for forests. For Ecol Manag 259:660-684

Andrew ME, Wulder MA, Cardille JA (2014) Protected areas in boreal Canada: a baseline and considerations for the continued development of a representative and effective reserve network. Environ Rev 22:135-160

Angelstam P, Andersson L (2001) Estimates of the needs for forest reserves in Sweden. Scand J For Res (Suppl) 3:38-51

Angelstam P, Axelsson R, Elbakidze M, Laestadius L, Lazdinis M, Nordberg M, Patru-Stupaiu I, Smith M (2011) Knowledge production and learning for sustainable forest management on the ground: Pan-European landscapes as a time machine. Forestry. https://doi.org/10.1093/forestry/cpr048

Angers VA, Gauthier S, Drapeau P, Jayen K Bergeron Y (2011). Tree mortality and snag dynamics in North American boreal tree species after a wildfire: a longterm study. Internat J Wildl Fire: 20(6):751-763

Auvinen A-P, Hildén M, Toivonen H, Primmer E, Niemelä J, Aapala K, Bäck S, Härmä P, Ikävalko J, Järvenpää E, Kaipiainen $H$, Korhonen KT, Kumela $H$, Kärkkäinen L, Lankoski J, Laukkanen M, Mannerkoski I, Nuutinen T, Nöjd A, Punttila P, Salminen O, Söderman G, Törmä M, Virkkala R (2007) Evaluation of the Finnish National Biodiversity Action Plan 1997-2005. Monogr Boreal Environ Res 29:1-55

Bartemucci P, Coates KD, Harper KA, Wright EF (2002) Gap disturbances in northern old-growth forests of British Columbia, Canada. J Veg Sci 13:685-696

Bauhus J, Puettmann C, Messier C (2009) Silviculture for old-growth attributes. For Ecol Manag 258:525-537

Bélisle AC, Gauthier S, Cyr D, Bergeron Y, Morin H (2011) Fire regime and oldgrowth boreal forests in Central Quebec, Canada: an ecosystem management perspective. Silva Fenn 45:889-908

Berg Å, Ehnström B, Gustafsson L, Hallingbäck T, Jonsell M, Weslien J (1994) Threatened plant, animal and fungus species in Swedish forests: distribution and habitat associations. Cons Biol 8(3):718-731

Bergeron Y, Fenton N (2012) Boreal forests of eastern Canada revisited: old growth, nonfire disturbances, forest succession and biodiversity. Botany 90: $509-523$

Bergeron Y, Gauthier S, Flannigan M, Kafka V (2004) Fire regimes at the transition between mixed wood and coniferous boreal forest in northwestern Quebec. Ecology 85:1916-1932 
Bergeron Y, Gauthier S, Kafka V, Lefort P, Lesieur D (2001) Natural fire frequency for the eastern Canadian boreal forest: consequences for sustainable forestry. Can J For Res 31:384-391

Bergeron Y, Harvey B, Leduc A, Gauthier S (1999) Forest management guidelines based on natural disturbance dynamics: stand- and forest-level considerations. For Chron 75:55-61

Bergeron Y, Leduc A, Harvey B, Gauthier S (2002) Natural fire regime: a guide for sustainable management of the Canadian boreal forest. Silva Fenn 36(1):81-95

Blarquez O, Carcaillet C, Frejaville T, Bergeron Y (2014) Disentangling the trajectories of alpha, beta and gamma plant diversity of north American boreal ecoregions since 15,500 years. Front Ecol Evol 2:1-8

Boucher D, Gauthier S, Noël J, Greene DF, Bergeron Y (2014). Salvage logging affects early post-fire tree composition in Canadian boreal forest. For Ecol Manage 325:118-127

Boulanger Y, Gauthier S, Burton PJ (2014) A refinement of models projecting future Canadian fire regimes using homogeneous fire regime zones. Can J For Res 44(4):365-376. https://doi.org/10.1139/cjfr-2013-0372

Boulanger $Y$, Sirois L (2007) Postfire succession of saproxylic arthropods, with emphasis on Coleoptera, in the north boreal black spruce forest of Québec. Env Entomol 36:128-141

Bradshaw CJA, Warkentin IG (2015) Global estimates of boreal forest carbon stocks and flux. Glob Planet Change 128:24-30

Bradshaw CJA, Warkentin IG, Sodhi NS (2009) Urgent preservation of boreal carbon stocks and biodiversity. Trends Ecol Evol 24:541-548

Brandt JP, Flannigan MD, Maynard DG, Thompson ID, Volney WJA (2013) An introduction to Canada's boreal zone: ecosystem processes, health, sustainability, and environmental issues. Environ Rev 21(4):207-226

Burton PJ (2013). Exploring complexity in boreal forests. In:Messier C, Puettmann KJ, Coates KD (eds.). Managing forests as complex adaptive systems. Building resilience to the challenge of global change. Routledge, New York. pp. 79-109

Burton PJ, Bergeron Y, Bogdanski BEC, Juday GP, Kuuluvainen T, BJ MA, Ogden A, Teplyakov VK, Alfaro RI, Francis DA, Gauthier S, Hantula J (2010) Sustainability of boreal forests and forestry in a changing environment. In: Mery G, Katila P, Galloway G, Alfaro RI, Kanninen M, Lobovikov M, Varjo J (eds) Forests and Society - Responding to Global Drivers of Change. International Union of Forest Research Organizations (IUFRO), Vienna, pp 249-282

Burton PJ, Kneeshaw DD, Coates KD (1999) Managing forest harvesting to maintain old growth in boreal and sub-boreal forests. For Chron 75:623-631

Burton PJ, Macdonald SE (2011) The restorative imperative: challenges, objectives and approaches to restoring naturalness in forests. Silva Fenn 45(5):843-863

Burton PJ, Messier C, Puettmann KJ, Coates KD (2013) Exploring complexity in boreal forests. Managing forests as complex adaptive systems. Building resilience to the challenge of global change. Routledge, London, pp 79-109

Burton PJ, Messier C, Weetman GF, Prepas EE, Adamowicz WL, Tittler R (2003) The current state of boreal forestry and the drive for change. In: Burton PJ, Messier C, Smith DW, Adamowicz WL (eds) Towards Sustainable Management of the Boreal Forest. NRC Research Press, Canada, pp 1-40

Cyr D, Gauthier S, Bergeron Y (2007) Scale-dependent determinants of heterogeneity in fire frequency in a coniferous boreal forest of eastern Canada. Landscape Ecol 22(9):1325-1339.

Carcaillet C, Richard PJH, Bergeron Y, Fréchette B, Ali AA (2010) Resilience of the boreal forest in response to Holocene fire-frequency changes assessed by pollen diversity and population dynamics. Int J Wildland Fire 19(8):1026-1039

Carleton TJ, Maclellan P (1994) Woody vegetation responses to fire versus clearcutting logging: a comparative survey in the Central Canadian boreal forest. Écoscience 1(2):141-152

Cyr D, Gauthier S, Bergeron Y (2007) Scale-dependent determinants of heterogeneity in fire frequency in a coniferous boreal forest of eastern Canada. Landscape Ecol 22(9):1325-1339

Cyr DS, Gauthier S, Bergeron Y, Carcaillet C (2009) Forest management is driving the eastern north American 1 boreal forest outside its natural range of variability. Front Ecol Environ 7(10):519-524. https://doi.org/10.1890/080088

Dukes JS, Pontius J, Orwig D, Garnas JR, Rodgers VL, Brazee N, Cooke B, Theoharides KA, Stange EE, Harrington R, Ehrenfeld J, Gurevitch J, Lerdau M, Stinson K, Wick $R$, Ayres M (2009) Responses of insect pests, pathogens, and invasive plant species to climate change in the forests of northeastern North America: what can we predict? Can J For Res 39(2):231-248. https://doi.org/10.1139/X08-171

EASAC (2017) Multi-functionality and sustainability in the European Union's forests. EASAC Policy Report 32, p 41

Esseen PA, Ehnström B, Ericson L, Sjöberg K (1997) Boreal forests. Ecol Bull 46:16-47
Fenton NJ, Bergeron Y (2008) Does time or habitat make old-growth forests species rich? Bryophyte richness in boreal Picea mariana forests. Biol Conserv 41(5):1389-1399

Finnish Statistical Yearbook of Forestry (2012). Finnish Foresr Research Institute. Vammalan Kirjapaino OY, Sastamala, Finland. 452 p

Flannigan MD, Krawchuk MA, de Groot WJ, Wotton M, Gowman LM (2009) Implications of changing climate for global wildland fire. Int J Wildland Fire 18(5):483-507

Flannigan MD, Logan KA, Amiro BD, Skinner WR, Stocks BJ (2005) Future area burned in Canada. Clim Chang 72:1-2): 1-16. https://doi.org/10.1007/s10584-005-5935-y

Gauthier S, Bernier P, Burton PJ, Edwards J, Isaac K, Isabel N, Jayen K, Le Goff H, Nelson EA (2014) Climate change vulnerability and adaptation in the managed Canadian boreal forest. Environ Rev 22(3):256-285. https://doi.org/ 10.1139/er-2013-0064

Gauthier S, Bernier P, Kuuluvainen T, Shvidenko AZ, Schepaschenko DG (2015a) Boreal forest health and global change. Science 349:819-822. https://doi.org/ 10.1126/science.aaa9092

Gauthier S, Bernier PY, Boulanger Y, Guo XJ, Guindon L, Beaudoin A (2015b) Vulnerability of timber supply to projected changes in fire regime in Canada's managed forests. Can J For Res 45:1439-1447. https://doi.org/10. 1139/cjfr-2015-0079

Gauthier S, Leduc A, Bergeron Y, Le Goff H (2009c) Fire frequency and forest management based on natural disturbances. In: Gauthier S, Vaillancourt M-A, Leduc A, De Grandpre L, Kneeshaw DD, Morin H, Drapeau P, Bergeron Y (eds) Ecosystem management in the boreal forest. Presses de I'Université du Québec, Québec, QC, pp 39-56

Gauthier S, Vaillancourt M-A, Kneeshaw DD, Drapeau P, De Grandpre L, Claveau Y, Pare D (2009a) Forest ecosystem management: origins and foundations. In: Gauthier S, Vaillancourt M-A, Leduc A, De Grandpre L, Kneeshaw DD, Morin $H$, Drapeau P, Bergeron Y (eds) Ecosystem Management in the Boreal Forest. Presses de I'Université du Québec, Québec, QC, pp 13-38

Gauthier S, Vaillancourt M-A, Leduc A, De Grandpré L, Kneeshaw D, Morin H, Drapeau P, Bergeron Y (2009b) Ecosystem Management in the Boreal Forest. Natural Resources Canada, Canadian Forest Service, Laurentian Forestry Centre, Quebec, Quebec, p 492

Girard F, Payette S, Gagnon R (2008) Rapid expansion of lichen woodlands within the closed-crown boreal forest zone over the last 50 years caused by stand disturbances in eastern Canada. J Biogeogr 35:529-537

Greene DF, Gauthier S, Noël J, Rousseau M, Bergeron Y (2006) A field experiment to determine the effect of post-fire salvage on seedbeds and tree regeneration. Front Ecol Environ 4:69-74

Groisman P, Shugart H, Kicklighter D, Henebry G, Tchebakova N, Maksyutov S, Monier E, Gutman G, Gulev S, Qi J, Prischepov A, Kukavskaya E, Porfiriev B, Shiklomanov A, Loboda T, Shiklomanov N, Nghiem S, Bergen K, Albrechtová J, Chen J, Shahgedanova M, Shvidenko A, Speranskaya N, Soja A, de Beurs K, Bylygina O, McCarty J, Zhuang Q, Zolina O (2017) Northern Eurasia Future Initiative (NEFI): facing the challenges and pathways of global change in the twenty-first century. Prog Earth Planetary Sci 4:41. https://doi.org/10.1186/ s40645-017-0154-5

Gromtsev A (2002) Natural disturbance dynamics in the boreal forests of European Russia: a review. Silva Fenn 36:41-55

Guindon L, Bernier PY, Beaudoin A, Pouliot D, Villemaire P, Hall RJ, Latifovic R, StAmant R (2014) Annual mapping of large forest disturbances across Canada's forests using 250 m MODIS imagery from 2000 to 2011. Can J For Res 44: 1545-1554

Halme P, Allen KA, Aunins A, Bradshaw RHW, Brumelis G, Cada V, Clear $J$, Eriksson A-M, Hannon G, Hyvärinen E, Ikauniece S, Iršènaitė R, Jonsson BG, Junninen K, Kareksela S, Komonen A, Kotiaho JS, Kouki J, Kuuluvainen T, Mazziotta A, Mönkkönen M, Nyholm K, Olden A, Shorohova E, Strange N, Toivanen T, Vanha-Majamaa I, Wallenius T, Ylisirniö A-L, Zin E (2013) Challenges of ecological restoration: lessons from forests in northern Europe. Biol Conserv 167:248-256

Hannah L, Midgley G, Andelman S, Araújo M, Hughes G, Martinez-Meyer E, Williams P (2007) Protected area needs in a changing climate. Front Ecol Environ 5(3):131-138

Hanski I (2000) Extinction debt and species credit in boreal forests: modelling the consequences of different approaches to biodiversity conservation. Ann Zool Fenn 37:271-280

Helmisaari H-S, Kaarakka L, Olsson BA (2014) Increased utilization of different tree parts for energy purposes in the Nordic countries. //dx.doi.org/10.1080/ 02827581.2014.926097. Accessed 21 May 2017 
Jasinski JPP, Payette S (2005) The creation of alternative stable states in the southern boreal forest, Québec, Canada. Ecol Monogr 75:561-583

Johnson EA (1992) Fire and vegetation dynamics: studies from the North American boreal forest. Cambridge Studies in Ecology. Cambridge University Press, Cambridge

Josefsson T, Hörnberg G, Östlund L (2009) Long-term human impact and vegetation changes in a boreal forest reserve: implications for the use of protected areas as ecological references. Ecosystems 12(6):1017-1036

Kafka V, Gauthier S, Bergeron Y (2001) Fire impacts and crowning in the borea forest: study of a large wildfire in western Quebec. Int J Wild Fire 10:119-127

Keto-Tokoi P, Kuuluvainen T (2014) Primeval forests of Finland. Cultural history, ecology and conservation. Maahenki 302, p

Kneeshaw D, Bergeron Y, Kuuluvainen T (2011) Forest ecosystem structure and disturbance dynamics across the circumboreal forest. In: Millington A, Blumler M, Schickhoff U (eds) Handbook of biogeography. Sage Publications, London

Kotiaho JS (2017) On effective biodiversity conservation, sustainaability of bioeconomy, and honesty of the Finnish forest policy. Ann Zool Fenn 54:1325 https://doi.org/10.5735/086.054.0104. Accessed 21 May 2017

Kouki J, Löfman S, Martikainen P, Rouvinen S, Uotila A (2001) Forest fragmentation in Fennoscandia: linking habitat requirements of woodassociated threatened species to landscape and habitat changes. Scand J For Res (Suppl) 3:27-37

Kuuluvainen T (2009) Forest management and biodiversity conservation based on natural ecosystem dynamics in northern Europe: the complexity challenge. Ambio 38:309-315

Kuuluvainen T (2016) Ecosystem management of the boreal forest. Oxford Encyclopedia of Environmental Science. https://doi.org/10.1093/acrefore/ 9780199389414.013.15

Kuuluvainen T, Aakala T (2011) Natural forest dynamics in boreal Fennoscandia: a review and classification. Silva Fenn 45(5):823-841

Kuuluvainen T, Grenfell R (2012) Natural disturbance emulation in boreal forest ecosystem management: theories, strategies and a comparison with conventional even-aged management. Can J For Res 42:1185-1203

Kuuluvainen T, Siitonen J (2013) Fennoscandian boreal forests as complex adaptive systems. Properties, management challenges and opportunities. In: Messier C, Puettmaan KJ, Coates KD (eds) Managing forests as complex adaptive systems. Building resilience to the challenge of global change. Earthscan, New York, pp 244-268

Kuuluvainen T, Tahvonen O, Aakala T (2012) Even-aged and uneven-aged forest management in boreal Fennoscandia: a review. Ambio 41(7):720-737

Langor DW, Cameron EK, McQuarrie CJK, McBeath A, McClay A, Peter B, Pybus M, Ramsfield T, Ryall K, Scarr T, Yemshanov D, DeMerchand I, Foottit R, Pohj GR (2014) Non-native species in Canada's boreal zone: diversity, impacts, and risk. Environ Rev 22:372-420

Leduc A, Bernier PY, Mansuy N, Raulier F, Gauthier S, Bergeron Y (2015) Using salvage logging and tolerance to risk to reduce the impact of forest fires on timber supply calculations. Can J For Res 45:480-486. https://doi.org/10.1139/ cjfr-2014-0434

Lindenmayer DB, Burton PJ, Franklin JF (2013) Salvage logging and its ecological consequences. Island Press, Australia

Lindenmayer DB, Franklin JF (2002) Conserving forest biodiversity. A comprehensive multiscaled approach. Island Press, Washington

Lindner M, Maroschek M, Netherer S, Kremer A, Barbati A, Garcia-Gonzalo J, Seidl R, Delzon S, Corona P, Kolström M, Lexer MJ, Marchetti M (2010) Climate change impacts, adaptive capacity, and vulnerability of European forest ecosystems. For Ecol Manag 259:698-709

Maynard DG, Paré D, Thiffault E, Lafleur B, Hogg KE, Kishchuk B (2014). How do natural disturbances and human activities affect soils and tree nutrition and growth in the Canadian boreal forest? Environ Rev 22(2):161-178

McAfee BJ, Camino RD, Burton PJ, Eddy B, Fähser L, Messier C, Reed MG, Spies T, Vides R, Baker C, Barriga M, Campos J, Corrales O, Espinoza L, Gibson S, Glatthorn J, Martineau-Delisle C, Prins C, Rose NA (2010) Managing forested landscapes for socio-ecological resilience. IUFRO International Union of Forestry Research Organizations, pp 401-439

McCarthy J (2001) Gap dynamics of forest trees: a review with particular attention to boreal forests. Environ Rev 9:1-59

McKenney DW, Pedlar JH, Papadopol P, Hutchinson MF (2006) The development of 1901-2000 historical monthly climate models for Canada and the United States. Agric For Meteorol 138(1):69-81

Millar Cl, Stephenson NL, Stephens SL (2007) Climate change and forests of the future: managing in the face of uncertainty. Ecol Appl 17:2145-2151
Moen J, Rist L, Bishop K, Chapin FS III, Ellison D, Kuuluvainen T, Petersson H, Puettmann KJ, Rayner J, Warkentin IG, Bradshaw CJA (2014) Eye on the taiga: removing global policy impediments to safeguard the boreal forest. Cons Lett 7(4):408-418. https://doi.org/10.1111/conl.12098

Nappi A, Dery S, Bujold F, Chabot M, Dumont M-C, Duval J, Drapeau P, Gauthier S, Brais S, Peltier J, Bergeron I (2011) Harvesting in Burned Forests — Issues and Orientations for Ecosystem-Based Management. Ministère des Ressources naturelles et de la Faune, Direction de l'environnement et de la protection des forêts, Québec, p 47

Nappi A, Drapeau P, Saint-Germain M, Angers VA (2010) Effect of fire severity on long-term occupancy of burned boreal conifer forests by saproxylic insects and wood-foraging birds. Int J Wildland Fire 19:500-511

Nappi A, Drapeau P, Savard JP (2004) Salvage logging after wildfire in the boreal forest: is it becoming a hot issue for wildlife? For Chron 80(1):67-74

Nguyen-Xuan T, Bergeron Y, Simard D, Fyles JW, Paré D (2000) The importance of forest floor disturbance in the early regeneration patterns of the boreal forest of western and Central Quebec: a wildfire versus logging comparison. Can J For Res 30:1353-1364

Nordén J, Penttilä R, Siitonen J, Tomppo E, Ovaskainen O (2013) Specialist species of wood-inhabiting fungi struggle while generalists thrive in fragmented boreal landscapes. J Ecol 101:701-712

O'Neill GA, Ukrainetz NK, Carlson MR, Cartwright CV, Jaquish BC, King JN, Krakowski J, Russell JH, Stoehr M, Xie C-Y, Yanchuk AD (2008) Assisted migration to address climate change in British Columbia: recommendations for interim seed transfer standards. BC Ministry of Forests and Range, Research Branch, Victoria For Sci Branch Tech Rep, p 48

Pan Y, Birdsey RA, Fang J, Houghton R, Kauppi PE, Kurz WA, Phillips OL, Shvidenko A, Lewis SL, Canadell JG, Ciais P, Jackson RB, Pacala SW, McGuire AD, Piao S, Rautiainen A, Sitch S, Hayes D (2011) A large and persistent carbon sink in the world's forests. Science 333:988-994

Payette S (1992) Fire as a controlling process in the north American boreal forest. In: Shugart HH, Leemans R, Bonan GB (eds) A systems analysis of the global boreal forest. Cambridge University Press, New York, pp 144-169

Pedlar JH, McKenney DW, Aubin I, Beardmore T, Beaulieu J, Iverson L, O'Neill GA, Winder RS, Ste-Marie C (2012) Placing forestry in the assisted migration debate. BioScience 62(9):835-842

Pennanen J (2002) Forest age distribution under mixed-severity fire regimes - a simulation-based analysis for middle boreal Fennoscandia. Silva Fenn 36:213-231

Peura M, Burgas D, Eyvindson K, Repo A, Mönkkönen M (2018) Continuous cover forestry is a cost-efficient tool to increase multifunctionality of boreal production forests in Fennoscandia. Biol Conserv 217:104-112

Pickett STA, White PS (eds) (1985) The ecology of natural disturbance and patch dynamics. Academic Press, New York, p. 472

Price DT, Alfaro RI, Brown KJ, Flannigan MD, Fleming RA, Hogg EH, Girardin MP, Lakusta T, Johnson M, McKenney DW, Pedlar JH, Stratton T, Sturrock RN, Thompson ID, Trofymov JA, Venier LA (2013) Anticipating the consequences of climate change for Canada's boreal forest ecosystems. Environ Rev 21(4): 322-365

Puettmann KJ, Coates KD, Messier C (2009) A critique of silviculture: managing for complexity. Island Press, Washington, DC

Pukkala T (2016) Which type of forest management provides most ecosystem services? Forest Ecosystems 3:9. https://doi.org/10.1186/s40663-016-0068-5

Pukkala T, Lähde E, Laiho O, Salo K, Hotanen J-P (2011) A multifunctional comparison of even-aged and uneven-aged forest management in a boreal region. Can J For Res 41:851-862. https://doi.org/10.1139/X11-009

Pukkala T, Laiho O, Lähde E (2016) Continuous cover management reduces wind damage. For Ecol Manag 372:120-127

Rämö J, Tahvonen O (2014) Economics of harvesting of uneven-aged forest stands in Fennoscandia. Scan J For Res. https://doi.org/10.1080/02827581. 2014.982166

Rassi P, Hyvärinen E, Juslén A, Mannerkoski I (2010) The 2010 red list of Finnish species. Ympäristöministeriö \& Suomen Ympäristökeskus, Helsinki, p 685

Raulier F, Le Goff H, Gauthier S, Rapanoela R, Bergeron Y (2013) Introducing two indicators for fire risk consideration in the management of boreal forests. Ecol Indic 24:451-461

Raunio A, Schulman A, Kontula T (2008) The assessment of threatened habitat types in Finland - part 1: results and basis for assessment. Finnish Environment Institute, Helsinki, p 264 (in Finnish with English summary).

Régnière J, St-Amant R, Duval P (2012) Predicting insect distributions under climate change from physiological responses: spruce budworm as an example. Biol Invasions 14:1571-1586 
Rijal B (2017) A forest management decision support system for sustainable management of flammable boreal forest landscapes. Ph.D. Thesis. Département de Sciences du Bois et de la Forêt. Université Laval

Rogers BM, Soja AJ, Goulden ML, Randerson JT (2015) Influence of tree species on continental differences in boreal fires and climate feedbacks. Nat Geosci. https://doi.org/10.1038/NGEO2352

Saint-Germain M, Greene DF (2009) Salvage logging in the boreal and cordilleran forests of Canada: integrating industrial and ecological concerns in management plans. For Chron 85(1):120-134

Sánchez-Pinillos M, Coll L, De Cáceres M, Ameztequi A (2016) Assessing the persistence capasity of communities facing natural disturbances on the basis on species response traits. Ecol Indicators. https://doi.org/10.1016/j.ecolind. 2016.01.024. Accessed 21 Sept 2017

Savage DW, Martell DL, Wotton BM (2010) Evaluation of two risk mitigation strategies for dealing with fire-related uncertainty in timber supply modelling. Can J For Res 40(6):1136-1154

Seymour RS, Hunter ML (1992) New forestry in eastern spruce-fir forests: principles and applications to Maine (Vol. 716). College of Forest Resources, University of Maine

Scheffer M, Hirota M, Holmgren M, van Nes EH, Chapin FS (2012) Thresholds for boreal biome transitions. Proc Nat Aca Sci USA 109:21384-21389

Schmiegelow FK, Stepnisky DP, Stambaugh CA, Koivula M (2006) Reconciling salvage logging of boreal forests with a natural-disturbance management model. Cons Biol 20(4):971-983

Shorohova E, Kneeshaw D, Kuuluvainen T, Gauthier S (2011) Variability and dynamics of old-growth forests in the circumboreal zone: implications for conservation, restoration and management. Silva Fenn 45:785-806

Shorohova E, Kuuluvainen T, Kangur A, Jogiste K (2009) Natural stand structures, disturbance regimes and successional dynamics in the Eurasian boreal forests: a review with special reference to Russian studies. Ann For Sci 66(2):201

Siitonen J (2001) Forest management, coarse woody debris and saproxylic organisms: Fennoscandian boreal forests as an example. Ecol Bull 49:11-41

Stevens-Rumann CS, Kemp KB, Higuera PE, Harvey BJ, Rother MT, Donato DC, Morgan P, Veblen TT (2017) Evidence for declining forest resilience to wildfires under climate change. Ecol Lett https://doi.org/10.1111/ele.12889. Accessed 21 Sep 2017

Suffling, R, Smith, B, Molin, JD (1982). Estimating past forest age distributions and disturbance rates in north-western Ontario: a demographic approach. Journal of Environmental Management, 14(1), 45-56.

Swanson ME, Franklin JF, Beschta RL, Crisafulli CM, DellaSala DA, Hutto RL, Lindenmayer DB, Swanson FJ (2011) The forgotten stage of forest succession: early-successional ecosystems on forest sites. Front Ecol Environ 9(2):117-125

Tabor K, Williams JW (2010) Globally downscaled climate projections for assessing the conservation impacts of climate change. Ecol Appl 20:554-565

Thorn S, Bässler C, Brandl B, Burton BJ, Cahall R, Cambell JL, Castro J, Choi C-Y, Cobb T, Donato DC, Durska E, Fontaine JB, Gauthier S, Hebert C, Hothorn T, Hutto RL, Lee E-J, Lrverkus AB, Lindenmayer DB, Obrist MK, Rost J, Seibold S, Seidl R, Thom D, Waldron K, Wermelinger B, Winter M-B, Zmihorski M, Muller J (2017) Impacts of salvage logging on biodiversity: a meta-analysis. J Appl Ecol. https://doi.org/10.1111/1365-2664.12945

Venier LA, Thompson ID, Fleming R, Malcolm J, Aubin I, Trofymov JA, Langor D, Sturrock R, Patry C, Outerbridge RO, Holmes SB, Heussler S, De Grandpré L, Chen HYH, Bayne E, Arsenault A, Brandt JP (2014) Effects of natural resource development on the terrestrial biodiversity of Canadian boreal forests. Eviron Rev 22:457-490

Waldron K, Ruel J-C, Gauthier S (2013) Forest structural attributes after windthrow and consequences of salvage logging. For Ecol Manag 289:28-37

Whittaker RH (1975) Communities and Ecosystems. 2d ed. Macmillan, New York

\section{Submit your manuscript to a SpringerOpen ${ }^{\odot}$ journal and benefit from:}

- Convenient online submission

- Rigorous peer review

- Open access: articles freely available online

- High visibility within the field

- Retaining the copyright to your article

Submit your next manuscript at $\gg$ springeropen.com 